\title{
Involvement of Aeromonads and Pseudomonads in Diseases of Farmed Fish in Bangladesh
}

\author{
Md. Bazlur Rashid Chowdhury \\ Department of Aquaculture, Faculty of Fisheries, Bangladesh Agicultural University, \\ Mymensingh, Mymensingh 2202, Bangladesh
}

(Received February 13, 1998)

\begin{abstract}
Studies were conducted to investigate the bacterial infection in the farmed freshwater fishes of Bangladesh. Fishes in a number of farms were found to suffer from diseases expressing different kinds of skin lesions, tail and fin rot, gills damage etc. From the high numbers of aeromonads and pseudomonads in the lesions and kidney of the affected fish, these bacteria were suspected to be involved in those diseases in carp and catfish. The present study describes their occurrences in different aquaculture facilities including fishes, their resistance to various antibacterial agents, survival of some selected isolates in different waters and pathogenicity of the selected isolates. Both aeromonad and pseudomonad isolates were found to possess multiple patterns of resistance to the antibacterial agents tested. The selected isolates showed similar survival patterns in the experimental waters tested. Tap water, pond water and saline supported the long-term survival of both aeromonads and pseudomonads. Among the selected aeromonad isolates, Aeromonas hydrophila was confirmed experimentally to cause an ulcer type of disease in the farmed catfish, Clarias gariepinus. In the case of pseudomonads, the isolate PMR-3 recovered from the kidney of a diseased carp (Puntius gonionotus) produced disease suceessfully in $P$. gonionotus.
\end{abstract}

Key words: Aeromonas, Pseudomonas, antibiotic, drug resistance, pathogenicity, carp, catfish

Bangladesh has a vast and variety of aquatic resources in the form of rivers, canals, floodplains, lakes, ponds, estuaries and a long sea coast displaying high diversity in their biotic and abiotic characteristics. Total freshwater area is 4.35 million hectares and marine water area 16.6 million hectares. Production of fisheries organisms especially fish and shrimp are substantially important in the food and economy of Bangladesh in terms of nutrition, income, employment generation and foreign exchange earning. Total fish production in Bangladesh during the year 1996-97 was about 1.37 million metric tons of which 1.07 million metric tons produced from freshwater including culture fisheries and 0.3 million metric tons from marine water including shrimp. About $14 \%$ of the foreign exchange is earned from the fisheries sector and $80 \%$ of the animal protein intake in the country comes from fish. Overall, fish production from cap-

Name and address of correspondence: Dr. Md. Bazlur Rashid Chowdhury, Professor

Department of Aquaculture, Faculty of Fisheries, Bangladesh Agricultural University, Mymensingh, Mymensingh 2202, Bangladesh Tel.: 880-91-52236 (Office) 880-91-53690 (Residence) Fax: $880-91-55810$ ture fisheries i.e., direct harvesting from natural aquatic resources is gradually decreasing. To overcome the problem aquaculture practices have been increased in the country.

At present, disease has become one of the major limiting factors in fish production in Bangladesh, especially with the recent increase of aquaculture practices. Diseases like epizootic ulcerative syndrome (EUS), different kinds of skin lesions, red coloured body, gill damage, tail and fin rot type disease are very common in both farmed and wild fishes of Bangladesh (Chowdhury, 1993). In the last few years these diseases had become a tremendous threat to fish production in Bangladesh. The outbreak of EUS in freshwater fishes often become alarming to increase fish production in the country. Although the intensity of the incidence of EUS is now decreasing but still it is threat to many farmed fishes in the country.

Farmers often confuse the EUS with the other diseases of similar lesions appearing on the body surface of fish which are not the typical EUS. In order to get release from these diseases immediately, they often use some chemicals including antibiotics. But the farmers hav- 
ing no proper knowledge of fish health management, have to fail in most cases to control the disease. Research on the fish diseases especially on bacterial or other microbial diseases is very poor in the country having insufficient facilities in terms of laboratory and trained personnel. In the circumstances, the Faculty of Fisheries under Bangladesh Agricultural University got an opportunity to establish an equiped Fish Disease Laboratory in the country in 1993 under a collaboration with the Institute of Aquaulture, University of Stirling financed by the British ODA.

Considering the importance and immediate need for the country research works on the bacterial disease of fish have been started systematically and developed step by step since 1993 . In the first attempt, aeromonads and pseudomonads were taken for the study on the basis of a preliminary investigation on the diseases of farmed fishes in Bangladesh. The present paper will describe some of the useful aspects of these two groups of bacteria such as status of the load of these bacteria in the water, sediments and fishes of different aquaculture facilities in Bangladesh, their resistance to various antibacterial agents, suvival of some selected isolates in different water conditions and pathogenicity of the selected isolates including the isolates recovered from diseased fish.

\section{Materials and Methods}

\section{Investigation of fish disease in Bangladesh}

An investigation on the outbreak of diseases in the farmed fishes of Bangladesh was carried out during 1991-1993. At first, in 1991 a survey was performed taking data and information from the fish farmers, farm managers or the fishery officers of a particular locality or thana area. They provided the data from 1988 when the outbreak of EUS started in the country. In total 150 ponds under 40 fish farms throughout the country were taken for investigation. In 1992-1993 the data for the disease incidence were recorded by the graduate researchers by taking fish samples from the same locality, fish farms and ponds. Incidence of disease was categorised into the outbreak of typical EUS, appearance of spots and various types of lesions other than EUS, tail and fin rot type disease, parasitic infection (ectoparasites) and the unknown diseases. The investigated farmed fish species were the carps (Labeo rohita, Catla catla, Cirrhinus mrigala, Puntius gonionotus, Hypophthalmicthys molitrix), and catfishes (Clarias batrachus, C. gariepinus, Clarias sp. hybrid, Pungasius sutchi).

\section{Sampling}

In total 30 fish ponds under 10 fish farms were selected to monitor the total bacterial load, aeromonads and pseudomonads contents in the water, sediments, fish body surface (slime) and kidney. The data were collected from 10 samplings scheduled once in a month. The selected farms were in the district of Mymensingh and Gazipur (Dhaka), viz., Dhaka Fisheries Ltd., Bangladesh Catfish Farm Ltd. Trishal fish farm, Mashkanda fish farm, BFRI fish farm, University fish farm, Faculty fish farm, Shambuganj fish farm, Jhalak fish farm and Gouripur government fish farm. Fish were sampled from the three ponds of each these farms. The regular sampled fish species were $L$. rohita, $C$. catla, C. mrigala, $P$. gonionotus and $C$. gariepinus. In total 120 fish were collected in the 10 samplings for each fish species. All the sampling sites were within $2 \mathrm{~h}$ driving distance from the Faculty of Fisheries, and the samples were brought to the laboratory immediately after collection for bacteriological study.

\section{Determination and isolation of bacteria}

The total bacterial load in the water, sediments, and fish slime and kidney were determined on Trypton Soya Agar (TSA, Oxoid) by the conventional plate culture method. Aeromonads were determined on a selective medium Aeromonas-Agar Base (Oxoid) plate supplemented with ampicillin SR 136 E (commercial code) which was found to be a suitable medium for isolation and determination of aeromonads (Chowdhury and Inglis, 1994b). Pseudomonads were determined on another selective medium, Pseudomonas Agar Base (Oxoid) plate supplemented with antibiotic C-F-C (Cetrimide-Fucidin-Cephaloridine) SR 103 E (commercial code). This medium was previously proved to be a suitable medium for isolation and determination of pseudomonads from fish, water or soil (Chowdhury and Inglis, 1994a). Ten fold dilutions of samples were made in sterile saline $(0.85 \% \mathrm{NaCl})$ whenever necessary for all cases and the inoculated plates were incubated at $25^{\circ} \mathrm{C}$ for $24 \mathrm{~h}-48 \mathrm{~h}$. Aeromonad and pseudomonad isolates were carefully separated aseptically from the freshly cultured plates containing $50 \sim 80$ colonies depending on the colony shape, size and colour. Special attention was drawn to recover the isolates from the kidney and lesions of the affected fish in order to isolate the suspected pathogens. 


\section{Drug sensitivity test}

Discs of six antibacterial agents were used for the sensitivity test of the recovered aeromonad and pseudomonad isolates. A protocol previously developed under a collaborative research (Chowdhury and Inglis, 1994a, 1994b) was applied for the present investigation. The drug discs (Oxoid Ltd.) were of chloramphenicol $(30 \mu \mathrm{g} /$ disc), oxytetracycline ( $30 \mu \mathrm{g} / \mathrm{disc})$, sulphamethoxazole ( $25 \mu \mathrm{g} / \mathrm{disc})$, erythromycin $(10 \mu \mathrm{g} / \mathrm{disc})$, streptomycin $(10 \mu \mathrm{g} / \mathrm{disc})$ and oxolinic acid $(2 \mu \mathrm{g} / \mathrm{disc})$. A suspension of the individual isolate prepared in sterile saline was spreaded over the Iso-sensi Test Agar (Oxoid) plate. After inoculation the above mentioned six antibiotic discs were dispensed uniformly with the help of Oxoid Unipath Disc Dispenser Mark II and incubated at $25^{\circ} \mathrm{C}$. Result of the drug sensitivity was recorded after $24 \mathrm{~h}$ of incubation and expressed as resistant (R) when the growth was normal, or sensitive with the zone of inhibition (measured in $\mathrm{mm}$ ) having no growth around the drug disc. The zone of confusing growth around the disc was noted as \pm . In all 240 isolates comprising 120 aeromonads and 120 pseudomonads recovered from water, sediments and various fish species were tested for the drug sensitivity.

\section{Survival test of aeromonad and pseudomonad isolates}

Five aeromonad and five pseudomonad isolates were selected to observe their survival patterns in different types of experimental water. These isolates were selected on the basis of their high multiple resistance to the antibacterial agents and recovery from the diseased fish. The experimental waters were distilled water, deionized water, saline water, tap water, Faculty Pond (FP) water and the University Pond (UP) water. Individual isolates were cultured on TSA at $25^{\circ} \mathrm{C}$ for 18-24h. A stock suspension of the bacterial isolate was prepared with the young culture harvesting $30 \sim 50 \mathrm{mg}$ aseptically and dissolved in $10 \mathrm{~m} l$ of autoclaved distilled water. An amount of $0.5 \mathrm{~m} l$ stock suspension was inoculated in the $100 \mathrm{~m} l$ pre-prepared sterile (autoclaving) individual experimental water. Bacterial numbers were determined at $0,1,3,5,7$ and 10 days maintaining at $25^{\circ} \mathrm{C}$. Conventional plate culture method was used to determine the bacterial number $(\mathrm{CFU} / \mathrm{m} l)$ by incubating at $25^{\circ} \mathrm{C}$.

\section{Pathogenicity test of the selected isolates}

Two species of young disease-free fish maintained in the experimental ponds were selected for experimental infection. These were further acclimatized to aquarium conditions before use in the experiment. The first one is a catfish, $C$. gariepinus weighing $25-30 \mathrm{~g}$ and the second one is a carp, P. gonionotus of 10-12 $\mathrm{g}$ in weight. Two sets of experiments by using water-borne infection method (contact by immersion) were conducted to examine the pathogenicity of the isolates for the two fish species. In the case of pseudomonad isolates, only $P$. gonionotus was used for experimental infection. The stock suspension of the bacteria was prepared in sterile tap water with $18-24 \mathrm{~h}$ culture. In a $30 l$ capacity aquarium, $15 l$ of bacterial suspension was prepared in the tap water with the stock suspension in such way that the bacterial density became $3-5 \times 10^{8} \mathrm{CFU} / \mathrm{ml}$. This exposure dose of bacteria was selected by a preliminary experiment. Five fish were exposed to bacterial suspension in the aquarium under aerated condition at room temperature (water temperature ranged $24-25^{\circ} \mathrm{C}$ ). After $24 \mathrm{~h}$ of exposure $80 \%$ of the bacterial suspension was exchanged with tap water and from the following day $50 \%$ of water was exchanged at every $24 \mathrm{~h}$. In the same way another set of experiment was maintained. Two replications were set up for the same isolate and the experiments were repeated for confirmation of infection, and thus in total 20 fish were used for single fish species against the individual bacterial isolate. The infection was detected by the appearance of lesion and mortality. Experimental period was 10 days. For each set of experiment control fish were maintained in the same way. No food were applied during the experimental period.

\section{Identification of the selected aeromonads}

The bacterial isolates, AJR-3, ABG-8, ADG-3, AGM5, and AMP-3 which were tested of their survival in different waters and pathogenicity were characterized in detail to identify them on the species level. Morphological, physiological and biochemical characteristics were studied following the methods described in the books edited by Barrow and Feltham (1993), Frerichs and Millar (1993), and Krieg and Holt (1984). For confirmation of the identification comparative characterization was conducted with the known strains of Aeromonas hydrophila (a Japanese strain and a Thai strain).

\section{Results}

\section{Incidence of disease}

Incidence of fish diseases in the 150 surveyed ponds under 40 fish farms throughout Bangladesh were 50 
$60 \%$ EUS, $40 \sim 70 \%$ spot and other lesions, $20 \sim 30 \%$ tail and fin rot type disease, $10 \sim 20 \%$ parasitic infection, especially ectoparasitic infection and $10 \sim 15 \%$ unknown disease during 1988-91 (Table 1). In the following years (1992-93) incidence of EUS was lower (25 30\%) which were investigated by sampling from the same ponds under the same farms. However, the incidence of the other mentioned diseases were more or less similar to those recorded for $1988 \sim 91$.

\section{Bacterial load}

Bacterial numbers in the water and sediments of the fish ponds were found to vary significantly. The total bacterial load in the water sampled from 30 fish ponds under 10 fish farms in Mymensingh and Gazipur districts ranged $1.7 \times 10^{4} \sim 4.4 \times 10^{5} \mathrm{CFU} / \mathrm{m} l$ and those in the sediments ranged $1.3 \times 10^{5} \sim 5.6 \times 10^{6} \mathrm{CFU} / \mathrm{g}$. The number of aeromonads in the pond water ranged $3.2 \times 10^{3} \sim 2.5 \times 10^{4} \mathrm{CFU} / \mathrm{m} l$ and those in the sediments varied from $4.5 \times 10^{3}$ to $5.3 \times 10^{5} \mathrm{CFU} / \mathrm{g}$, whereas the number of pseudomonads ranged $1.4 \times 10^{3} \sim 2.1 \times 10^{4}$ $\mathrm{CFU} / \mathrm{ml}$ in the water and $1.5 \times 10^{3} \sim 3.5 \times 10^{5} \mathrm{CFU} / \mathrm{g}$ in the sediments. Bacterial loads in the slime and kidney of different farmed fishes, viz., L. rohita, C. catla, $C$. mrigala, $P$. gonionotus and $C$. gariepinus are shown in Table 2. The total bacterial population, aeromonads and pseudomonads were always found to be high in the slime compared with those observed in the kidney. However, in the case of diseased fish bacterial load in the kidney, especially aeromonads were very high in number (up to $3.2 \times 10^{6} \mathrm{CFU} / \mathrm{g}$ ) in $C$. gariepinus. Bacterial loads were found to be highly variable from one species of fish to another. C. catla carried comparatively low content of bacteria than the other species of fish. In most cases aeromonads were found to be dominant in number than pseudomonads. The lowest total content of bacteria recorded in the kidney of $C$. catla $\left(3.4 \times 10^{3} \mathrm{CFU} / \mathrm{g}\right)$ and the highest was recorded in the slime of $C$. gariepinus $\left(3.7 \times 10^{7} \mathrm{CFU} / \mathrm{g}\right)$ followed by $C$. mrigala $\left(3.3 \times 10^{7} \mathrm{CFU} / \mathrm{g}\right)$. The lowest content of aeromonads and pseudomonads were recorded in $C$. catla, $1.4 \times 10^{3}$ and $1.5 \times 10^{3} \mathrm{CFU} / \mathrm{g}$, respectively. The highest number of aeromonads were obtained in the slime of $C$. gariepinus and those of pseudomonads were obtained in the slime of $C$. mrigala.

Table 1. Investigation of fish disease occurrence in the farmed fishes of Bangladesh

\begin{tabular}{|c|c|c|c|c|c|c|c|c|}
\hline \multirow{2}{*}{$\begin{array}{c}\text { Year of } \\
\text { investigation }\end{array}$} & \multirow{2}{*}{$\begin{array}{l}\text { No. of } \\
\text { farms }\end{array}$} & \multirow{2}{*}{$\begin{array}{l}\text { No. of } \\
\text { ponds }\end{array}$} & \multirow[b]{2}{*}{ Fish } & \multicolumn{5}{|c|}{ Incidence of diseases (\%) } \\
\hline & & & & EUS & $\begin{array}{l}\text { Spot \& } \\
\text { lesions }\end{array}$ & $\begin{array}{l}\text { Tail \& } \\
\text { fin rot }\end{array}$ & $\begin{array}{l}\text { Parasitic } \\
\text { infection }\end{array}$ & $\begin{array}{l}\text { Unknown } \\
\text { disease }\end{array}$ \\
\hline $1988-91^{\mathrm{a}}$ & 40 & 150 & Carps \& catfish & $50 \sim 60$ & $40 \sim 70$ & $20 \sim 30$ & $10 \sim 20$ & $10 \sim 15$ \\
\hline $1992-93^{b}$ & 40 & 150 & Carps \& catfish & $25 \sim 30$ & $50 \sim 60$ & $15 \sim 25$ & $15 \sim 20$ & $15 \sim 20$ \\
\hline
\end{tabular}

a: The data was based on the observation by the farmers, farm managers, or the fishery officers.

b: The data was based on the observation and sampling by the researchers.

Table 2. Bacterial load in the slime and kidney of different farmed fishes in Bangladesh

\begin{tabular}{|c|c|c|c|c|}
\hline \multirow{2}{*}{ Fish species } & \multirow{2}{*}{ Organ } & \multicolumn{3}{|c|}{ Range of bacterial number (CFU/g) } \\
\hline & & Total content & Aeromonads & Pseudomonads \\
\hline \multirow[t]{2}{*}{ L. rohita } & Slime & $4.4 \times 10^{5} \sim 6.5 \times 10^{6}$ & $1.8 \times 10^{5} \sim 2.7 \times 10^{6}$ & $3.6 \times 10^{4} \sim 5.2 \times 10^{5}$ \\
\hline & Kidney & $5.7 \times 10^{3} \sim 4.3 \times 10^{5}$ & $2.3 \times 10^{3} \sim 3.8 \times 10^{5}$ & $1.8 \times 10^{3} \sim 1.6 \times 10^{4}$ \\
\hline \multirow[t]{2}{*}{ C. catla } & Slime & $8.7 \times 10^{4} \sim 3.5 \times 10^{5}$ & $2.5 \times 10^{4} \sim 1.2 \times 10^{5}$ & $1.7 \times 10^{4} \sim 1.3 \times 10^{5}$ \\
\hline & Kidney & $3.4 \times 10^{3} \sim 1.2 \times 10^{4}$ & $1.4 \times 10^{3} \sim 1.3 \times 10^{4}$ & $1.5 \times 10^{3} \sim 2.1 \times 10^{4}$ \\
\hline \multirow[t]{2}{*}{ C. mrigala } & Slime & $2.2 \times 10^{6} \sim 3.3 \times 10^{7}$ & $5.2 \times 10^{5} \sim 1.8 \times 10^{6}$ & $1.6 \times 10^{4} \sim 5.5 \times 10^{5}$ \\
\hline & Kidney & $3.1 \times 10^{4} \sim 7.2 \times 10^{5}$ & $6.7 \times 10^{3} \sim 4.5 \times 10^{5}$ & $2.3 \times 10^{3} \sim 1.2 \times 10^{5}$ \\
\hline \multirow[t]{2}{*}{$P$. gonionotus } & Slime & $2.6 \times 10^{5} \sim 8.2 \times 10^{5}$ & $1.5 \times 10^{4} \sim 2.7 \times 10^{5}$ & $3.8 \times 10^{3} \sim 1.3 \times 10^{5}$ \\
\hline & Kidney & $2.3 \times 10^{4} \sim 5.7 \times 10^{5}$ & $1.2 \times 10^{4} \sim 3.6 \times 10^{5}$ & $1.9 \times 10^{3} \sim 2.8 \times 10^{4}$ \\
\hline \multirow[t]{2}{*}{ C. gariepinus } & Slime & $6.8 \times 10^{6} \sim 3.7 \times 10^{7}$ & $1.7 \times 10^{6} \sim 2.5 \times 10^{7}$ & $1.5 \times 10^{4} \sim 3.9 \times 10^{5}$ \\
\hline & Kidney & $3.3 \times 10^{4} \sim 3.5 \times 10^{6}$ & $2.1 \times 10^{4} \sim 3.2 \times 10^{6}$ & $4.5 \times 10^{3} \sim 5.1 \times 10^{4}$ \\
\hline
\end{tabular}

The data obtained from 120 individuals of each fish species in 10 samplings. 
Drug sensitivity of bacteria

The distribution of the resistant isolates among the total isolates tested (each 120 isolates for aeromonads and pseudomonads) are shown in Table 3. Resistance patterns of aeromonads were likely to be similar to those of pseudomonads, although their prevalence of single, multiple (resistant to two or more drugs) and total resistance differed from each other. Prevalence of their resistance patterns to the antibacterial agents tested are shown in Fig. 1. In both the cases, prevalence of resistance was the highest to erythromycin followed by oxytetracycline and the lowest to oxolinic acid. However, prevalence of resistance to chloramphenicol, sulphamethoxazole and streptomycin were found to be moderate and similar to each other.

Table 3. Distribution of resistant isolates among the total isolates tested

\begin{tabular}{lcccc}
\hline \hline Bacteria & $\begin{array}{c}\text { Number of } \\
\text { isolates } \\
\text { tested }\end{array}$ & $\begin{array}{c}\text { Single } \\
\text { resistant }\end{array}$ & $\begin{array}{c}\text { Multiple } \\
\text { resistant }\end{array}$ & $\begin{array}{c}\text { Total } \\
\text { resistant }\end{array}$ \\
\hline Aeromonads & 120 & ${ }^{\mathrm{a}} 25(20.8)^{\mathrm{b}}$ & $55(45.8)$ & $80(66.7)$ \\
Pseudomonads & 120 & $30(25)$ & $45(37.5)$ & $75(62.5)$ \\
\hline
\end{tabular}

${ }^{\mathrm{a}}$ : Number, ${ }^{\mathrm{b}}$ : Percentage

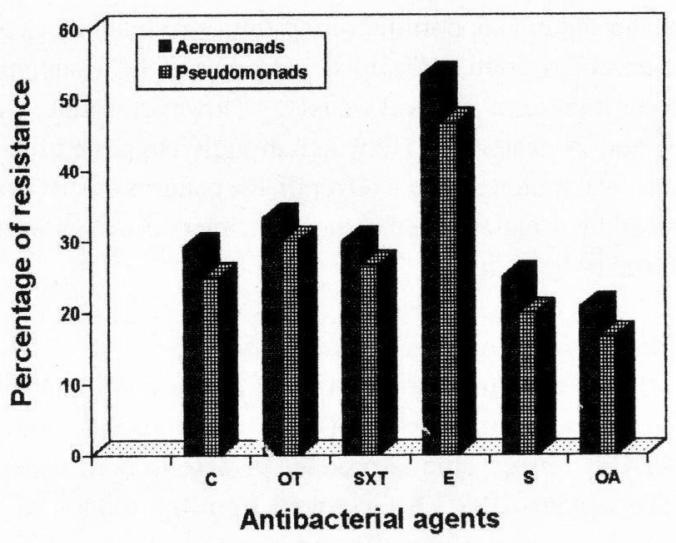

Fig 1. Prevalence of resistance patterns of aeromonads and pseudomonads to the antibacterial agents tested.

C : Chloramphenicol $(30 \mu \mathrm{g} /$ disc $)$

OT : Oxytetracycline ( $30 \mu \mathrm{g} / \mathrm{disc})$

SXT: Sulphamethoxazole $(20 \mu \mathrm{g} / \mathrm{disc})$

E : Erythromycin $(10 \mu \mathrm{g} /$ disc $)$

S : Streptomycin $(10 \mu \mathrm{g} /$ disc $)$

OA : Oxolinic acid $(2 \mu \mathrm{g} /$ disc $)$

\section{Survival of isolates in water}

Survival patterns of the five selected aeromonad and five pseudomonad isolates in different types of water are demonstrated in Table 4 . In both cases deionized

Table 4. Survival patterns of aeromonad and pseudomonad isolates in different experimental waters

\begin{tabular}{|c|c|c|c|c|c|c|}
\hline \multirow{2}{*}{$\begin{array}{l}\text { Bacterial } \\
\text { isolates }\end{array}$} & \multicolumn{6}{|c|}{ Survival support in the experimental waters } \\
\hline & $\begin{array}{l}\text { Distilled } \\
\text { water }\end{array}$ & $\begin{array}{c}\text { Deionized } \\
\text { water }\end{array}$ & $\begin{array}{l}\text { Saline } \\
\text { water }\end{array}$ & $\begin{array}{c}\text { Tap } \\
\text { water }\end{array}$ & $\begin{array}{c}\text { FP } \\
\text { water }\end{array}$ & $\begin{array}{c}\text { UP } \\
\text { water }\end{array}$ \\
\hline \multicolumn{7}{|l|}{ Aeromonds } \\
\hline AJR-3 & + & - & ++ & ++ & ++ & +++ \\
\hline ABG-8 & + & - & ++ & +++ & ++ & ++ \\
\hline ADG-3 & + & - & +++ & ++ & ++ & ++ \\
\hline AGM-5 & + & - & ++ & +++ & ++ & +++ \\
\hline AMP-3 & + & - & ++ & ++ & +++ & +++ \\
\hline \multicolumn{7}{|c|}{ Pseudomonads } \\
\hline PDC-4 & + & - & ++ & +++ & ++ & ++ \\
\hline PJM-6 & + & - & ++ & ++ & ++ & +++ \\
\hline PMR-3 & + & - & +++ & ++ & ++ & ++ \\
\hline PSM-2 & + & - & ++ & ++ & ++ & +++ \\
\hline PBG-7 & + & - & ++ & ++ & +++ & ++ \\
\hline
\end{tabular}

-: Did not support

+: Weak long-term support

++ : Strong long-term support

+++ : Very strong long-term support 
water did not sopport their long-term survival of any of the isolates tested. Distilled water was found to support their logn-term survival weakly. However, saline, tap water, FP water and UP water strongly supported their survival for long-term. Overall, the patterns of survival of all the isolates tested in the experimental waters were more or less similar.

\section{Pathogenicity and taxonomy of isolates}

In the experimental infection of $C$. gariepinus and $P$. gonionotus by the five selected aeromonad isolates, only ABG-8 was capable to produce disease in both fishes. The isolate ABG - 8 recovered from the kidney of a farmed $C$. gariepinus affected by an ulcer type of disease was sussessful to produce similar type of lesion in the experimental fish (100\% in C. gariepinus and $90 \%$ in $P$. gonionotus). It caused mortalities $75 \%$ in $C$. gariepinus and $80 \%$ in $P$. gonionotus. No disease condition was induced by the other isolates tested as well as in the control fishes. In the case of the five selected pseudomonad isolates, the isolate PMR-3 recovered from the kidney of a diseased carp ( $P$. gonionotus) produced disease in P. gonionotus. Even $100 \%$ fish died within 10 days of experiment. However, the other isolates were not able to produce disease in the fish tested as like as the control fish.

The detalied characterization in comparison with the known strains, $A$. hydrophila FPC 344 (Japan) and $A$. hydrophila AAHRI (Thailand) confirmed ABG-8 isolate as A. hydrophila (Table 5). The isolates AJR-3 and ADG-3 were also

A. hydrophila but their pathogenicity could not be detected. The isolates AGM-5 and AMP-3 were identified as $A$. sobria considering that these were negative

Table 5. Characteristics of the recorvered two aeromonad isolates with the known A. hydrophila strains

\begin{tabular}{|c|c|c|c|c|}
\hline \multirow[t]{2}{*}{ Characteristics } & \multicolumn{2}{|c|}{ Aeromonad isolates } & \multirow{2}{*}{$\begin{array}{c}\text { A. hydrophila } \\
\text { FPC 344, Japan }\end{array}$} & \multirow{2}{*}{$\begin{array}{c}\text { A. hydrophila } \\
\text { AAHRI, Thailand }\end{array}$} \\
\hline & ABG-8 & AGM-5 & & \\
\hline Gram's staining & - & - & - & - \\
\hline Shape & $\mathbf{R}$ & $\mathbf{R}$ & $\mathrm{R}$ & $\mathbf{R}$ \\
\hline Diffusible brown pigment & - & - & - & - \\
\hline Motility & + & + & + & + \\
\hline Growth in air & + & + & + & + \\
\hline Growth anaerobically & + & + & + & + \\
\hline Catalase & + & + & + & + \\
\hline Oxidase & + & + & + & + \\
\hline Glucose O-F test & $\mathrm{F}$ & $\mathrm{F}$ & $\mathrm{F}$ & $\mathrm{F}$ \\
\hline Growth at $37^{\circ} \mathrm{C}$ & + & + & + & + \\
\hline Resistance to $0 / 129(150 \mu \mathrm{g})$ & + & + & + & + \\
\hline$\beta$-galactosidase (ONPG) & + & + & + & + \\
\hline Arginine dihydrolase & + & + & + & + \\
\hline Ornithine decarboxylase & - & - & - & - \\
\hline Lysine decarboxylase & + & + & + & + \\
\hline $\mathrm{H}_{2} \mathrm{~S}$ production & + & + & + & + \\
\hline Indole production & + & + & + & + \\
\hline Gelatin hydrolysis & + & + & + & + \\
\hline Aesculin hydrolysis & + & - & + & + \\
\hline Voges-Proskauer reaction & + & d & + & + \\
\hline L-histidine \& L-arginine utilization & + & - & + & + \\
\hline Urease activity & - & - & - & - \\
\hline Acid from: arabinose & + & - & + & + \\
\hline glucose & + & + & + & + \\
\hline inositol & - & - & - & - \\
\hline mannitol & + & + & + & + \\
\hline salicin & + & - & + & + \\
\hline sucrose & + & + & + & + \\
\hline
\end{tabular}

$\mathrm{R}$ : rod, $\mathrm{F}$ : fermentation, $\mathrm{d}$ : variable reaction 
to aesculin hydrolysis and could not produce acid from arabinose or salicin. Identification of the selected pseudomonad isolates are not yet confirmed.

\section{Discussion}

Bangladesh has been suffering from the outbreak of various kinds of diseases in both cultured and wild fish since 1988 and the disease has been a limiting factor in fish production. Investigation on fish diseases in the farmed fishes under the present study revealed that in every year there are a remarkable incidence of fish diseases in Bangladesh. It was suspected that many of these diseases were being caused by bacterial pathogens. As there was no systematic research on bacterial fish disease in Bangladesh, nobody could confirm the bacterial infection in fish until the present work started. Even in the report prepared by Roberts et al. (1989) on the survey of ulcerative disease in Bangladesh bacterial infection was not clearly explained.

Many scientists had keen interest to work on the incidence of EUS. It has been remarked that initially there was a common trend to suspect and investigate the bacterial involvement, especially the involvement of Aeromonas spp. in the outbreak of EUS (Roberts et al., 1989; Subasinghe et al.,1990; Torres et al., 1990; Karunasagar et al., 1995). However, the trend has become changed due to confirmation of the EUS pathogen, Aphanomyces invaderis, a fungus (Willoughby et al., 1995). For the other ulcer type of disease, it is quite natural to suspect the bacterial involvement. Variation in the bacterial load in the fish body surface (slime) and kidney, especially some times the unusual high number of Aeromonas spp. indicated their involvement or association with the disease in the affected fish. It was alarming that a significant number of both aeromonads and pseudomonads were found to be resistant to the common antibacterial agents tested. Prevalence of the resistance were found to be very high to erythromycin. Many of these resistant isolates possessed multiple patterns of resistance to the drug tested. The causes of these resistance properties were not studied but the resistance is presumed to be developed due to illegal use of antibacterial drugs in the disease affected fish ponds and use of cow-dung carrying the drug wastes. In the previous study these resistance were observed to be plasmid mediated (Chowdhury and Inglis, 1994a, 1994b).

The long-term survival of the selected isolates in the pond water and tap water (under ground water often uses in the pond) indicated that both Aeromonas spp. and Pseudomonas spp. can easily survive in the fish pond for longer period and can take the opportunity to infect fish easily when the fish become weak by various factors. The interesting achievement of the present study is the detection of the involvement of $A$. hydrophila causing an ulcer type of disease in the catfish $C$. gariepinus cultured in the fish farm because this is the first specific diagnosis made in the country. The strain designated as A. hydrophila ABG-8 was resistant to erythromycin, streptomycin and sulphamethoxazole. Among the other four selected isolates, two were A. hydrophila (AJR-3 and ADG-3) and two were A. sobria (AGM-5 and AMP-3) which were found unsuccessful to produce disease in the test fishes within the 10-day experimental period. Moreover, the study provides information that members of pseudomonads (not yet specifically identified) are also involved in the occurrence of disease in the aquaculture of Bangladesh. However, the present study is not a complete picture of bacterial infection in the fishes of Bangladesh. But it certainly provides an idea about the bacterial involvement in the outbreak of diseases in the farmed fishes of Bangladesh. Moreover, the knowledge of this study will help the fish farmers and culturists to take care in the use of antibiotics against the bacterial diseases of fishes under Bangladesh aquaculture.

\section{Acknowledgements}

The author expresses his sincere appreciation and thanks to all of the young scientists under the Fish Disease Laboratory, Faculty of Fisheries, Bangladesh Agricultural University, the graduate students of the author for their cooperation and help in the research works and to prepare the manuscript. A part of the work was supported by the ODA-BAU Link Project.

\section{References}

Barrow, G. I. and R. K. A. Feltham (editors and revisers) (1993): Cowan and Steel's manual for the identification of medical bacteria, Third ed., Cambridge Univ. Press, Cambridge, $331 \mathrm{p}$.

Chowdhury, M. B. R. (1993) : Research priorities for microbial fish disease and its control in Bangladesh. In "Proceedings of the workshop on research priorities in Bangladesh for fish health, disease prevention and pathology, 17th May 1993 Mymensingh" (ed. by A. Tollervey). British ODA in Bangladesh, pp. 8-11.

Chowdhury, M. B. R. and V. Inglis (1994 a) : Study on the resistance of pseudomonads in fish ponds of Bangladesh to 
some antibacterial agents. In "Proceedings of the International Congress on quality veterinary services for the $21 \mathrm{st}$ century,15-17 November 1994, Kualalumpur, Malaysia" (ed. by M. K. Vidyadaran, M. T. Aziz and H. Sharif). Department of Veterinary Services, Ministry of Agriculture, Malaysia, pp. 78-83.

Chowdhury, M. B. R. and V. Inglis (1994 b) : Selection of resistent aeromonads to certain antibacterial agents in the aquaculture sites of Bangladesh. In "Proceedings (report) of the workshop on the antibiotic resistance, 16-20 November 1994, AAHRI, Bangkok". The ODA SEAADCP, Department of Fisheries AAHRI, Bangkok, pp. 1-19.

Frerichs, G. N. and S. D. Millar (1993): Manual for the isolation and identification of fish bacterial pathogens, Pisces Press, Stirling, $60 \mathrm{p}$.

Karunasagar, I.,G. Sugumar and I. Karunasagar (1995): Virulence characters of Aeromonas spp. isolated from EUSaffected fish. In "Diseases in Asian Aquaculture II" (ed. by M. Shariff, J. R. Arthur and R. P. Subasinghe). Fish Health Section, Asian Fisheries Soc., Manila, pp. 307-314.

Krieg, N. R. and J. G. Holt (1984): Bergey's manual of systematic bacteriology,Vol. 1. Williams \& Willkins, Baltimore/ London, $964 \mathrm{p}$.
Roberts, R. J., R. Wotten, I. MacRae, S. Miller and W. Struthers (1989): Ulcerative disease survey, Bangladesh. Final report to the Government of Bangladesh and the Overseas Development Administration: Institute of Aquaculture, Stirling Univ., Scotland, 104 p.

Subasinghe, R. P., L. P. Jayasinghe, K. S. W. Balasuriya and M. Kulathilake (1990) : Preliminary investigations into the bacterial and fungal pathogens associated with the ulcerative fish disease syndrome in Sri Lanka. In "Proceedings of the Second Asian Fisheries Forum, 17-22 April 1989, Tokyo, Japan" (ed. by R. Hirano and I. Hanyu). Asian Fisheries Soc., Manila, pp. 655-657.

Torres, J. L., M. Shariff and A. T. Law (1990) : Identification and virulence screening of Aeromonas spp. isolated from healthy and epizootic ulcerative syndrome (EUS)-infected fish. In "Proceedings of the Second Asian Fisheries Forum, 17-22 April 1989, Tokyo, Japan” (ed. by R. Hirano and I. Hanyu). Asian Fisheries Soc., Manila, pp. 663-666.

Willoughby, L. G., R. J. Roberts and S. Chinabut (1995): Aphanomyces invaderis sp. nov., the fungal pathogen of freshwater tropical fish affected by epizootic ulcerative syndrame. J. Fish. Dis., 18, 273-275. 